Chapman University

Chapman University Digital Commons

8-19-2021

Campus Racial Climate, Boundary Work and the Fear and Sexualization of Black Masculinities on a Predominantly White University

Quaylan Allen

Follow this and additional works at: https://digitalcommons.chapman.edu/education_articles

Part of the African American Studies Commons, Educational Assessment, Evaluation, and Research Commons, Educational Sociology Commons, Gender and Sexuality Commons, Higher Education Commons, Other Education Commons, and the Race and Ethnicity Commons 


\section{Campus Racial Climate, Boundary Work and the Fear and Sexualization of Black Masculinities on a Predominantly White University}

\section{Comments}

This is a pre-copy-editing, author-produced PDF of an article accepted for publication in Men and Masculinities in 2021 following peer review. The definitive publisher-authenticated version is available online at https://doi.org/10.1177/1097184X211039002.

\section{Copyright}

The author 


\title{
Campus Racial Climate, Boundary Work and the Fear and Sexualization of Black Masculinities on a Predominantly White University
}

\begin{abstract}
This paper presents data from a study of Black men and masculinities at a predominantly White university. I argue that the campus racial climate on predominantly White universities are important sites of boundary work where fear and sexualization of Black masculinities are normalized in ways that shape Black men's social relations on college campuses. In doing so, I will share narrative data of how Black male college students perceive the campus racial climate, with a focus on how they are feared and sexualized in predominantly White spaces. I also analyze the ways in which they managed race, gender and sexuality within school spaces, and situate their gendered performances within the context of the boundary work of the university. Attention will be given to their agency in how they respond to White fears and sexualization of Black men.
\end{abstract}

Key words: Black males, campus racial climate, masculinities, sexualities 


\section{Campus Racial Climate, Boundary Work and the Fear and Sexualization of Black Masculinities on a Predominantly White University}

\section{Introduction}

Research on higher education has increasingly focused on examining the campus racial climate on predominantly White institutions (PWI) and its impact on the educational experiences of students of color (Fischer, 2010; Harper \& Hurtado, 2007; Henry, Fowler, \& West, 2011; Johnson, 2012; Park, 2014). Black male enrollment in institutions of higher education continues to increase, and many will attend PWIs that have campus racial climates described as being racially hostile to students of color (Feagin, Vera, \& Imani, 1996; Harper, Smith, \& Davis, 2016; Hurtado, 2015). Campus racial climate refers to the overall racial environment of the university, which might include its racial composition, curricular and co-curricular diversity, the frequency of racial incidents and the institutions response to racial inequities (Harper \& Hurtado, 2007; Hurtado, 2015; Solorzano, Ceja, \& Yosso, 2000). A poor racial climate negatively impacts the academic opportunity and success of Black students (Smith, Hung, \& Franklin, 2011; Steele, 1997), and Black students attending PWIs regularly report negative racialized experiences and campus climates (W. G. Harris, 2003; Solorzano, Ceja, \& Yosso, 2000; Tynes, Rose, \& Markoe, 2013).

Many of these experiences exist at a particular intersection of race and gender for Black men, where they are marginalized because they are Black and male. The xenophobia of the Black male body contributes to how Black men continue to be positioned in social and political discourses as a threat to society, unintelligent, hypermasculine and aggressive, and their bodies are sexualized and fetishized (Alexander, 2012; Fanon, 1967; hooks, 2003; Saint-Aubin, 2002). 
These discourses of fear and sexualization play out, and are perpetuated through, ideological institutions such as schools (Althusser, 2006; Smith, Allen, \& Danley, 2007). Universities in particular, are contested institutions of social and cultural reproduction (Bourdieu, 1977), and as specific sites of racial and gender socialization and reproduction, universities are locations in which Black masculinities are learned and practiced within dominant discourses of Black male pathology (Dancy, 2011; Strayhorn \& Tillman-Kelly, 2013). Many Black men attending PWIs will then learn and perform gender within poor campus racial climates.

For instance, Black men attending PWIs often have their presence on campus questioned by others and are made to feel invisible in campus spaces (Lewis, Chesler, \& Forman, 2000; Smith et al., 2007; Turner, 1994). They are often feared and avoided by students and faculty, and are subject to hypersurveillance and over-policing on campus (Smith et al., 2007; Solorzano et al., 2000; Wilkins, 2012b). Within the classroom, Black men are academically stereotyped and assumed to be less intelligent than their classmates and are often avoided by their peers during group projects (Fischer, 2007; Gleditsch \& Berg, 2017; Solorzano et al., 2000). Furthermore, research shows that White faculty tend to hold lower academic expectations for Black males, and limit their interactions with Black male students (Comeaux, 2013; Harper, 2009; Kim, 2010). Additionally, Black men on campus are often assumed to be cisgender, heterosexual and athletes, and gay Black men have described how racism, homophobia, and heteronormativity intersect in particular ways that inform their educational experiences and sense of belonging (W. G. Harris, 2003; Nadal et al., 2011; Strayhorn \& Tillman-Kelly, 2013; Wilkins, 2012b; Woodford, Howell, Kulick, \& Silverschanz, 2013). Moreover, White students who assume Black male sexual prowess, desire and seek out sexual experiences specifically with Black males based on these presumptions (Wilkins, 2012b). 
A poor racial climate in which Black men experience these types of racial discrimination sets the context in which dominant ideologies of Black masculinities are imposed, and where ontological installments of gender play out. Thus a poor racial climate not only impacts Black men's sense of belonging, school engagement and educational opportunity, but also contributes to the gender socialization of Black college men, and the reproduction of racial inequalities through schooling (Harper \& Hurtado, 2007; Smith et al., 2007).

In this paper, I argue that the campus racial climate on PWIs are important sites of boundary work where fear and sexualization of Black masculinities are normalized in ways that shape Black men's social relations on college campuses. In doing so, I will share narrative data of how Black male college students perceive the campus racial climate, with a focus on how they are feared and sexualized in predominantly White spaces. I also analyze the ways in which they managed race, gender and sexuality within school spaces, and situate their gendered performances within the context of the boundary work of the university. Attention will be given to their agency in how they respond to White fears and sexualization of Black men.

\section{Black Masculinities and Boundary work}

Scholars argue that gender is a socially constructed concept that is informed by dominant regimes of truth and relationships to power (Butler, 1988; Gardiner, 2005). As a collection of performances and practices, gender is brought into being performatively (1988), which is to say that gender is discursively constructed, and involves the repetition, citation and iterability of particular dominant gender norms. These dominant norms inform how masculinities are produced, which masculinities are acknowledged over others, and how men might take up or subvert such gender expectations (Brickell, 2005; Whitehead \& Barrett, 2001). 
For Black men in America, racism is endemic to everyday life and discourse, thus they will perform gender within particular racialized regimes of truth (Foucault, 1979; Hall, Critcher, Jefferson, Clarke, \& Robert, 1978; hooks, 2003). Black men are both idolized and feared, and as the racialized 'other', their polemical bodies are seen as both a threat and a commodity to a White, patriarchal, capitalist society (Entman \& Rojecki, 2000; Saint-Aubin, 2002; White, 2011). Though Black men have agency in their masculine expressions, they are also expressively constrained by the endemicity of racism and the correlative dominant discourses of Black male identity that might limit when and where Black men can perform certain masculinities.

Furthermore, as a discursive practice, gender is learned and practiced across various locations, including socializing institutions such as schools. Universities in particular, are important sites in which ideologies and expectations regarding gender and race are learned through the explicit and hidden curriculum of the campus racial climate and enactment of institutional norms (Harper \& Harris, 2010; Margolis, 2001; Ray \& Rosow, 2010; Smith et al., 2011). As such, it is important to examine PWIs and their campus racial climate as locations in which dominant normative gender expectations, and the boundary work that supports such expectations, shape social interactions among institutional actors (Barth, 1969; Gerson \& Peiss, 1985; Lamont \& Molnár, 2002; Ray \& Rosow, 2010).

Boundaries are important sites to analyze racial and gender relations on PWIs as boundaries mark the social spaces and contexts of Black male relations on college campuses. Boundary work distinguishes racial and gender groups from each other, and through social cues or normative assumptions, signify who is included or excluded, what boundaries can be crossed, by whom and under what conditions (Barth, 1969; Gerson \& Peiss, 1985). Boundary work within educational institutions contributes to inequitable stratification as racial and gender 
boundary work can serve to exclude Black men from particular educational and social opportunities (Lamont \& Molnár, 2002; Pachucki, Pendergrass, \& Lamont, 2007). Research on Black college men describes how boundary work at the university shapes the social interactions of Black students through physical and symbolic cues, assumptions, and institutional arrangements that are used to determine the inclusion and exclusion of certain groups, social control over college environments, and what behaviors are more or less acceptable in particular contexts (Ray \& Rosow, 2010; Wilkins, 2012a).

Such boundary work happens at PWIs and is rooted in larger racial and gender stereotypes about Black men that discursively position Black men as deviant, unintelligent, hypermasculine heterosexual, cisgender and hypersexual. This boundary work is employed in the way that Black men on PWIs are feared, avoided, and exoticized by White peers and faculty, or in the way that Black men's bodies are regulated through hypersurveillance and over-policing on campus. (Lewis et al., 2000; Smith et al., 2007; Solorzano et al., 2000; Wilkins, 2012b). Each of these experiences exemplify how boundary work shapes Black men's social interactions on campus, and happens through anti-Black racism that symbolically, physically and materially influences campus climate and Black male opportunity.

As raced, gendered and sexualized bodies on college campuses, boundary work is experienced at particular intersections where Black men's gender and sexual performances are demarcated. On PWIs Black men are assumed to be cisgender, heterosexual, and having sexual prowess, which contributes to the race, gender and sexual microaggressions Black queer and heterosexual men might experience (W. G. Harris, 2003; Strayhorn \& Tillman-Kelly, 2013; Wilkins, 2012b; Woodford et al., 2013). White students who assume Black male sexual prowess, desire and seek out sexual experiences specifically with Black men based on these presumptions 
(Wilkins, 2012b). Assumptions of Black male hypersexuality are rooted in legacies of racial eugenics and have been used to inform social, physical and legal boundaries that limit BlackWhite sexual relations. Black men's negotiation of their fear and sexualization on PWIs, points to the racial and gender boundaries that exist in school contexts, and Black men's agency in negotiating these boundaries. For instance, Black men in integrated settings such as PWIs are more aware of racial and gender boundaries, moreso than Black men in more segregated educational settings (Lacy, 2004; Young, 2004). Black men negotiate or resist these boundaries, enacting agency through particular performances of self, or by engaging in subversive, queer or progressive masculinities that challenge the racial and gender norms of the university (Author, 2018; Dancy, 2011; McGee \& Martin, 2011; McGuire, Berhanu, Davis, \& Harper, 2014; Strayhorn \& Tillman-Kelly, 2013). Still less is known about how Black men attending a PWI negotiate the racial and gender boundary work on campus, and how such boundary work contributes to the campus racial climate for Black male students.

\section{Research Methods and Data Sources}

Research overview and participants. The data presented in this paper derives from a qualitative study examining Black male college student success at a predominantly White liberal arts university. The research questions that inform the data presented in this paper were: 1) How do Black men experience and perceive the campus racial climate of the university as racialized and gendered individuals?, and 2) How do Black men respond to the campus racial climate of the university as racialized and gendered individuals? As a minoritized population on PWIs, purposive and snowball sampling methods were employed to recruit currently enrolled individuals identifying as a Black male undergraduate or graduate student (Goetz \& LeCompte, 
1984). This study includes 13 Black men, eight of which identified middle-class backgrounds and five identifying working-class backgrounds. Of the participants, 12 use he/him pronouns and one uses he/him, she/her pronouns. Additionally, eight students identify as heterosexual, four identify as gay, and one as bi-sexual.

The setting of this study was a private liberal arts university located in the western United States, and is situated in a wealthy, predominantly White county. Black students accounted for under two percent of the student population, and Black people in general made up less than two percent of the population in the surrounding county. Beyond the Black student organization, there were few resources or programs on campus that directly support the recruitment, social integration and educational success of Black students. Furthermore, despite the small population of Black people in the surrounding county, the local human relations commission consistently reported that the vast majority of hate crimes were targeted toward Black people. Thus, Black students attending the university found themselves in highly integrated settings where racialized interactions were not uncommon.

Data collection and analysis. In order to center the counterstories and the particular intersectional standpoints of the students (Crenshaw, 1993; Solórzano \& Yosso, 2002), a critical race theory (CRT) methodology was employed for this project. A CRT methodology seeks to challenge dominant ideologies and majoritarian narratives that position Black male students as deviant, anti-intellectual, and culturally deficient (Smith et al., 2007; Solorzano et al., 2000), and contribute to the boundary work that shapes Black men's social interactions on campus. Therefore, centering the experiential knowledge and counterstories of Black men through qualitative interviews is critical in contesting such majoritarian narratives and creates space for 
Black men to include their voices in racialized discourses about them (Solórzano \& Yosso, 2002).

The counterstories presented in this paper come from a series of three in-depth qualitative interviews conducted between 2015-2016. The open-ended semi-structured interviews were modeled in the fashion of Siedman's (1991) three-interview series. The first interview focused on their personal and K-12 educational biographies, the second interview focused on their college and work experiences, and the third interview concentrated on race, manhood and masculinities.

All of the interviews were audio recorded and transcribed. Analysis of the data followed a qualitative interpretive approach (Erickson, 1986) using NVivo qualitative data analysis software. First and second cycle coding methods were used on the data corpus (Saldana, 2009), and key linkages among different forms of data were identified. Initial assertions were tested against confirming and disconfirming evidence, and were organized into major themes and subthemes. Finally, I employed member-checking (Lincoln \& Guba, 1985) to improve the reliability of the data by sharing the transcripts, preliminary findings and final themes with participants throughout the project. During the final iteration of member checking, students provided the pseudonyms used in this paper.

\section{"He seems so aggressive": Fear of Black Masculinities}

The men in the study shared stories of their perception of the campus racial climate as Black men. Akin to Dubois' notion of double consciousness (1903), students described their constant awareness of White perceptions of Black male deviance, and their concern with how their behaviors and presentation of self might be misinterpreted. On campus, their presence was questioned by their peers or they were avoided by classmates. Faculty misinterpreted their 
assertiveness in the classroom as aggressive or defiant and all participants shared stories of their over-surveillance and racial profiling by campus and local law enforcement (Author, 2018).

For instance, the men described the ways they felt their behaviors were misinterpreted as aggressive. Isaiah, for instance, described his understanding of how Black men are perceived and how his own specific behaviors were interpreted as aggressive by others:

I think overall, Black men are perceived from their White and other [racial] counterparts, as being dominant, as being aggressive, as being direct. Also, people are afraid of them. People have told me that I am intimidating. I'm like, "Really? Me? Okay." I think it's more because I'm very direct. This is what I like and this is what I don't like. When Black men are assertive, it's mistaken for being aggressive. When White people are aggressive, they're being assertive or they're being very direct. What?

Other students also talked about how their behaviors were misinterpreted as aggressive, specifically by faculty. Carlos shared a story regarding a theater class that was discussing the history of blackface and minstrel shows. Carlos disagreed with an argument the instructor was making and as he explained:

She would get upset because I would be like "No, no that's not okay." Or I would have my opinion. She told another student, a friend of mine, "Isn't Carlos, he seems so aggressive. Isn't he just aggressive all the time? I just don't understand where it comes from." It seems like they [faculty] are somewhat intimidated. I feel they feel a sense of intimidation when they see Black males. Especially successful Black men, you know?

As numerical minorities, Black men in predominantly White settings must contend with racial stereotypes such as the "angry Black man" trope. These stereotypes serve as constraints to Black men's emotional and behavioral expressions (Jackson \& Wingfield, 2013) and contribute to the 
misinterpretation of Carlos' refusal to show deference in the classroom discourse. This type of racial boundary work on college campuses limits Black male expression in that Black men are prohibited from assertive behaviors without being labeled as deviant. As Isaiah points out, Black men's assertiveness is interpreted differently that White men's assertiveness. This also points to how Whiteness, and White masculinities in particular, can be a form of property (C. Harris, 1993; Wilkins, 2012a) on PWIs, in that certain masculine expressions on college campus seem to be reserved for White men. Black men, and other marginalized bodies, are excluded from the right to express a range of emotions, and are thus demarcated in what expressive boundaries they may or may not cross.

Fear of Black men also contributed to how students were avoided on campus. In his interview, The Giver explained how his peers would attempt to avoid him in certain campus spaces:

It feels like people are always avoiding me or trying to not sit next to me. Last semester I sat in the front for one of my classes. There was nobody else sitting in the front surprisingly, like everybody was trying to avoid sitting next to me. And coming from the residence halls on the shuttle - they don't want to sit next to me. I remember one time there was one space open next to me and someone stood. I'm like, Okay. You can be uncomfortable. I'm not. I don't know what it is. I know I look nice, but...

White student avoidance of Black men is also a form of boundary work, and Black men learn that their presence is unwelcomed and that they are considered a threat. Within the integrated nature of a PWI, the avoidance of Black men is both physical and symbolic boundary work and are moments in which Whites exert control over social contexts. This is also evident in how Black bodies are surveilled and policed on campus. As I have written elsewhere (Author, 2018), 
because of their minoritized status and hypervisibility on campus, Black men are highly surveilled by local law enforcement and the gaze of their peers. As a result of feeling under constant surveillance, the students expressed the dilemmas of being seen in groups of Black students and the self-consciousness they experience as a result. Braxton explains:

We talked about that at BSU maybe last semester. It's just this fear that we have subconsciously. I guess that if we acknowledge another African American person in public in front of, in this case it was the majority of White people, Caucasian people, we'll be seen as, "there goes Black people again doing those crazy handshakes and talking all loudly or saying hi” or whatever. When they see a group of three or more of us together it's just like so noticeable. "Oh, what are they doing? What, are they getting ready to dance or something?" I think that's why we [Black students] kind of see each other from afar and we're just passing by. Try not to say too much or attract too much attention, unfortunately.

The surveillance and policing of where Black bodies can exist, is a type of social control that is normalized within a PWI and mirrors the type of policing and surveillance Black bodies experience in the larger society (Bass, 2001; Hattery \& Smith, 2017; Weitzer, 2000). For students attending this PWI, racial boundaries are drawn that limit how and where they can congregate, and contribute to how they are avoided by their peers. Additionally, the boundary work of the university places limitations on their ability to express a range of emotions without social repercussions, and ultimately renders them both hypervisible and invisible at the same time. Many of these men responded to their experiences of being feared through a collection of repositioning practices and presentations of self (Author, 2018), that were acts of agency and performative strategies to navigate the campus racial climate of the university. Nevertheless, 
considering the raced and gendered microaggressions experienced by the men, it's clear that universities are important sites of racial and gender socialization, where Black men learn how they are viewed and what they are assumed to be.

\section{"You have a big one, huh?": Black male sexualization and negotiation}

Fears of Black male aggression and their physical presence on campus also draw upon a similar racist discourse of Black sexual deviance and prowess, which is a particular focus of this paper. The students shared how they were sexualized by their peers, and how White students frequently presumed Black sexual prowess, seeking out opportunities to exploit cisgender Black male sexualities. Both queer and heterosexual Black men in the study recognized their racialized sexual status and each responded in different ways to their sexualization. For instance, Apollo explained how many of his White male peers assumed his sexual prowess:

But again, it's like that stereotype almost. And I remember my freshman year, I was in [the residence halls], and I was talking to some dudes and they were talking about losing their virginities and whatever. And I was like "I haven't lost mine yet," and they looked at me like, "you're Black though? What are you? We've been here for three months already." And I was just like, like "dawg I know."

On PWIs, Black men are sometimes provided sexual status where the intersection of race, gender and sexual stereotypes of Black men interact with normative college sexual cultures. On PWIs Black men, and particularly high-status Black men such as athletes or fraternity men, are often the object of affection, particularly in heteronormative contexts (Ray \& Rosow, 2012). For instance, Terrell described how White female students hypersexualize straight Black men, explaining how for White women on campus, “There's this desire to sleep with them [heterosexual Black men] and some girls have a checklist. I want this one, that one, this one, that 
one.” Jay Blaze confirms this approach by women but also explains how such sexualization renders him both visible and invisible. He explained,

There's been a lot of people on campus who've been really over sexualizing the essence of a Black male. "Oh man you have the big thing, huh?" "Why are you asking me that? Why do you want to know?" They feel as though I'm a hot commodity. I'm in the minority. "Wouldn't it be great to sleep with a minority who's in charge?" It's not something they want to get to know. It's lust. They lust it but when they're around their friends and they see me they don't really want to look at me or lust at me anymore. They feel as though "I don't want to show my friends that I like this Black guy. I have jungle fever. I'm never going to go back to my friends ever again.”

The social interactions and relations between Black men and White students serve as form of boundary work where White students determine the type and quality of interactions with Black males, and where only certain masculinities are considered acceptable within the White hegemonic ideological context of a PWI. In the current study, it is White students who create boundaries in which Black men are avoided and expected to remain invisible until their presence satisfies White sexual interests. In the case of Jay, his body and sexuality are commodified through White desires, but also rendered invisible when his sexuality is no longer of White interest.

The sexualization of Black bodies is not exclusive to cisgender heterosexual Black men on PWIs and participants spoke of how Black women and queer men experience similar forms of racialized sexualization. In discussing how Black heterosexual men are sexualized, Terrell goes on to explain how Black women on campus can also be hypersexualized: 
Now it's like, they all want to see a Black girl twerk or be taught how to twerk. Young Black women on campus will be dancing at a party and they'll either be hypersexualized or judged. So, it's interesting that guys will pull out cameras and videotape it. It was just a lot going on...

The sexualization of Black women in many ways parallels Black male sexualization in that ontologies of Black female sexuality similarly position Black women as sexual bodies who are both objectified and demonized under the White male gaze (Dagbovie-Mullins, 2013; Magubane, 2002). Additionally, Isaiah shared his experience of sexualization explaining: Gay Black men are not excluded from this. A lot of people that are not Black have that big Black dick mentality. "Oh my gosh, this Black man has the biggest..." I've had people say, "I'd fuck with you," or, "We could have sex, but I wouldn't be in a relationship with you." I'm like, "Why?" And they say, "Because you're Black." Wow! Isaiah narrative brings attention to the sexual racism gay Black men might experience within LGBTQ+ communities, and collectively, the student's stories of racialized sexualization at a PWI point to the significance of race in shaping the boundaries that many Black bodies experience in predominantly White spaces. Furthermore, similar to Wilkins' (2012b) study of Black college men, the intersection of race, gender, and sexual stereotypes for Black men on predominantly White campuses is both stigma and status. While the sexual stereotypes of Black men might create opportunities for their own sexual exploration (F. Harris, Palmer, \& Struve, 2011), the men in this study also realized that such opportunities were relatively superficial and objectifying as their White peers seemed uninterested in them beyond sexual encounters. Additionally, these Black men must contend with confirming preconceived notions of their hypersexuality if they do pursue sexual encounters with peers. The racial boundary work on 
PWIs creates the context for particular types of Black sexualization and the campus becomes a performative stage in which Black men negotiate their racialized sexualization.

Black male negotiation. The boundary work on PWIs creates a context in which Black sexuality is mediated within the context of White fears of and desires for Black male bodies. The men in this study responded to their sexualization by negotiating sexual boundaries in different ways. In general, the men did not see their sexual practices as any different than other male college students. However, some men suppressed their sexuality in certain contexts to avoid assumptions of hypersexuality while others described their anxieties with the sexual expectations placed upon them. Still some men took advantage of sexual stereotypes about Black men while others rejected White sexual advances, recognizing that such advances were exploitative.

For instance, aware about their hypervisibility of campus and the history of Black male, White female sexual relationships, some men suppressed their sexuality or expressed a sense of hyperaccountability regarding how their sexual behaviors would be interpreted. Braxton explained:

I do think of what I do because of obviously who I am, and that if I do anything it could turn against me right away even though it may have been something completely opposite. Just because I'm one of 83 of whatever the number is. I would most likely be questioned, whatever it is, you know how that goes.

The suppression of their sexuality in spaces such as PWIs are reflective of what's known as respectable or decent masculinities (Wilkins, 2012b), gender performances that are rooted in Victorian middle-class sensibilities (Banner-Haley, 1994; Summers, 2004). Respectable masculinities are gender performances that respond to larger racial stereotypes of Black men through self-regulation and a self-emasculating presentation of self. Black men in integrated 
organizations are aware of such racial and sexual borders and men like Braxton negotiate these boundaries by attempting to reduce White fears and anxiety of Black male sexualities.

For other students, the sexual expectations placed on them created anxiety regarding their sexual practices, as they felt afraid that they would not live up to racial stereotypes that were supposedly giving them status on campus. James explained:

It's interesting because I don't know how other Black men feel, but I feel extremely pressured every time I have sex with someone. I feel like there's this expectation of I have to be great. I have to have a huge penis. I got to last all night. Especially in college when you're around non-Black women who were looking for that experience, you know what I mean? I shied away from it, to be honest with you. I was very hesitant just because I didn't want to be just an experience, and I didn't want all that pressure.

Similar to other studies on Black college men (Ray \& Rosow, 2010), most of the men in the current study preferred more romantic approaches to relationships with their partners, and described the importance of respecting their partner's bodies. However, in casual sexual encounters, Black men are exoticized through racial stereotypes of Black male sexual prowess, and experience a form of sexual double consciousness regarding their own sexual expectations and the sexual expectations placed upon them. Thus, as James explains, Black men are "an experience" for their non-Black peers, and though Black men might willingly participate in these interactions, they are subsequently dehumanized as commodities to be consumed by White voyeuristic desires. The extent of these intimate relationships are then limited by the boundaries of the sexual expectations of their White peers and Black men thus contend with the psychological stress and anxiety of performing dominant ontological assumptions of their sexuality (Lamb et al., 2018). 
Furthermore, as Black men often willingly engage in these relationships, it is also no surprise that students like Carlos took advantage of the sexual status that was afforded them:

At times I really could care less, I'm like yeah let's do it just because if that's what you want, that experience, I don't get so offended anymore about those things. It just doesn't faze me, so I'm just like hey what do I get out of it? Is there anything I get out of it? Well I guess I could have some sex and have some fun real quick, yeah whatever I don't care that it's just because I'm Black. Yeah, like it is what it is to me because I'm very aware. I'm not ignorantly like "oh yeah, I'm doing this because she's into me or he's into me." I definitely know what this is and what's going on but hey, whatever I'll play into it.

In her research on interracial intimacy among Black college men, Wilkins (2012b) explains that university status structures and racialized erotic markets intersect in ways that reward Black men for performing hypersexual behaviors. In this case, Carlos appropriates normative assumptions of Black male hypersexuality and the normative arrangements of the university by crossing racial boundaries through interracial intimacies. However, in subverting normative arrangements, his sexual agency involves his ability to deflect the racist intentions of the sexual encounter and appropriate his objectification as a source of personal enjoyment.

Finally, while not as common, men like Gabriel responded to their sexualization by calling out such behavior. He shares his response to how his White male peers sexualize him: I'm like, "Did you really just say that? That's really why you want to do that?" I can take a lot. I can control myself in a lot of environments like that. In that situation, I would use my power in a way, like just smoosh them down...Essentially, it just makes you feel like a piece of meat, like you're not an actual human being. I don't like being treated like that. 
Despite normative assumptions about Black men's sexual desires, it's clear that not all men desired to be sexually objectified and like Gabriel, might respond to the boundary work of the university by openly contesting the logic behind their objectification (McGuire et al., 2014), resisting White hegemony and sexual control over his body. What this section has highlighted though, are the different ways that Black men respond to their fear and sexualization on a predominately White campus and the ways in which their responses accommodate or resist White desires and expectations. Furthermore, the men's understandings of and responses to their racialized sexualization on campus point to the type of campus racial climate of the university, the dominant norms and assumptions used to include or exclude Black men from particular social relationships, and the way that the boundary work of the university limits Black men's gender and sexual performances.

\section{Conclusion and Implications}

Universities are important locations of racial and gender socialization, and the campus racial climate at PWIs are powerful sites of boundary work where fear and sexualization of Black masculinities are normalized in ways that shape the social interactions of Black men. The experiences of being feared, avoided, surveilled, and sexualized by White peers are some of the physical and symbolic social cues, normative assumptions, and institutional arrangements of the university that serve as the boundary work that includes or excludes Black men from particular social relations and educational opportunities. In this study, the students learned through the campus racial climate how dominant hegemonic ontologies of Black masculinities inform the racial and gender boundary work at the university that demarcates when they were included and excluded. The students learned when and where they would be made (in)visible on campus, what 
gender expressions would be available to them in the classroom, and what racial and sexual boundaries they could encounter.

Like other college Black men, the students in the study negotiated and responded to the campus racial climate in a range of ways (Author, 2018; Harper \& Quaye, 2007; McClure, 2006; McGee \& Martin, 2011), including learning to traverse the racialized assumptions placed upon them. However, their counterstories of the campus racial climate serve as important critiques to majoritarian narratives of Black college men and describes the ways that a poor campus racial climate negatively impacts the college experience of Black students attending PWIs (Gleditsch \& Berg, 2017; Hurtado, 2015; Kim, 2010).

Implications. This study sought to examine how Black college men made meaning of the campus racial climate and how they managed their intersectional identities within school spaces. Universities should continue to work to develop a positive campus racial climate that will improve the academic opportunity and success of its Black students (Fischer, 2010; Park, Denson, \& Bowman, 2013; Smith et al., 2011). This includes assessing the racial composition and curricular diversity of the institution, the types and frequencies of racial incidents that Black students experience, and how the university responds to such racial inequalities (Harper \& Hurtado, 2007; Hurtado, 2015; Solorzano et al., 2000). In particular, university administrators should acknowledge the role White supremacy, anti-Black racism, and xenophobia of the Black body might play in the way that their students, staff, and faculty interact with their Black cisgender, transgender and gender non-conforming students. Additionally, universities should review their own campus police practices to assess how social fears of Black men inform how campus officers surveil and interact with Black students. Moreover, it's also worth considering how particular types of sexualization of Black men might be considered a form of sexual 
harassment that often goes unreported on college campuses largely because of the assumptions that (Black) men desire to be sexualized, or the stigma tied to pushing against masculine sexual norms at college. University administrators should consider then how race and gender intersect in Black college men's sexual experiences when they educate their students and staff on issues of sexual harassment and assault prevention.

Future studies should continue examining Black male educational experiences at predominantly White liberal arts universities as these settings are understudied sites of racial, gender, and sexual socialization for Black college men (Stewart, 2017). Similar to the current study, researchers, and university administrators may want to qualitatively document Black men's perception of the racial and sexual climate of the university to understand how race, class, gender, and sexuality might intersect in the particular types of experiences that Black men have on campus. Finally, discussions regarding male sexualization are less common among men on college campuses and student affairs professionals might consider developing co-curricular programming in which men can engage in such discussions and share how they negotiate certain boundaries in college environments. 


\section{References}

Alexander, M. (2012). The New Jim Crow : Mass Incarceration in the Age of Colorblindness New York, NY: The New Press

Althusser, L. (2006). Ideology and ideological state apparatuses (notes towards an investigation). In A. Sharma \& A. Gupta (Eds.), The Anthropology of the State: A Reader (pp. 693-702): Blackwell Publishing.

Author. (2018). Details witheld for peer review.

Banner-Haley, C. T. (1994). The Fruits of Integration: Black Middle-Class Ideology and Culture, 1960-1990. Jackson: University Press of Mississippi.

Barth, F. (1969). Ethnic groups and boundaries. The social organization of culture difference. In: Bergen.

Bass, S. (2001). Policing Space, Policing Race: Social Control Imperatives and Police Discretionary Decisions. Social Justice(1), 156-176.

Bourdieu, P. (1977). Cultural Reproduction and social reproduction. In J. Karabel \& A. H. Halsey (Eds.), Power and Ideology in Education (pp. 487 - 511). New York: Oxford University Press.

Brickell, C. (2005). Masculinities, peformativity, and subversion: A sociological reappraisal. Men and Masculinities, 8(1), 24-43.

Butler, J. (1988). Performative Acts and Gender Constitution: An Essay in Phenomenology and Feminist Theory(4), 519.

Comeaux, E. (2013). Faculty Perceptions of High-Achieving Male Collegians: A Critical Race Theory Analysis. Journal of College Student Development, 54(5), 453-465. 
Crenshaw, K. (1993). Demarginalizing the Intersection of Race and Sex: A black feminist critique of antidiscrimination doctrine, feminist theory, and antiracist politics. In D. K. Weisberg (Ed.), Feminist Legal Theory (pp. p. 383 - 395). Philadelphia: Temple University Press.

Dagbovie-Mullins, S. A. (2013). Pigtails, Ponytails, and Getting Tail: The Infantilization and Hyper-Sexualization of African American Females in Popular Culture. Journal of Popular Culture, 46(4), 745-771.

Dancy, T. E. (2011). Colleges in the making of manhood and masculinity: gendered perspectives on African American males. Gender \& Education, 23(4), 477-495.

DuBois, W. E. B. (1903). The Souls of Black Folk. Chicago: A.C. McClurg and Co.

Entman, R., \& Rojecki, A. (2000). The Black Image in the White Mind: Media and Race in America. Chicago: The University of Chicago Press.

Erickson, F. (1986). Qualitative Methods in Research on Teaching. In M. C. Wittrock (Ed.), Handbook of research on teaching (3rd ed., pp. 119 - 161). New York: MacMillan.

Fanon, F. (1967). Black Skin, White Masks. New York: Grove Press.

Feagin, J. R., Vera, H., \& Imani, N. (1996). The agony of education : Black students at white colleges and universities: New York : Routledge, 1996.

Fischer, M. J. (2007). Settling into Campus Life: Differences by Race/Ethnicity in College Involvement and Outcomes. The Journal of Higher Education, 78(2), 125-161.

Fischer, M. J. (2010). A Longitudinal Examination of the Role of Stereotype Threat and Racial Climate on College Outcomes for Minorities at Elite Institutions. Social Psychology of Education: An International Journal, 13(1), 19-40.

Foucault, M. (1979). On Governmentality. Ideology and Consciousness, 6, 5 - 22. 
Gardiner, J. K. (2005). Men, Masculinities, and Femist Theory. In M. S. Kimmel, J. Hearn, \& R. W. Connell (Eds.), Handbook of Studies on Men and Masculinities (pp. 35 - 50). Thousand Oaks, CA: Sage Publications.

Gerson, J., M., \& Peiss, K. (1985). Boundaries, Negotiation, Consciousness: Reconceptualizing Gender Relations. Social Problems, 32(4), 317.

Gleditsch, R. F., \& Berg, J. A. (2017). Racial Attitudes of University Faculty Members: Does Interracial Contact Matter? Humboldt Journal of Social Relations, 39, 104-116.

Goetz, J. P., \& LeCompte, M. D. (1984). Ethnography and Qualitative Design in Educational Research. Orlando, FL: Academic Press, Inc.

Hall, S., Critcher, C., Jefferson, T., Clarke, J., \& Robert, B. (1978). Policing the Crisis: Mugging, the state and law and order. London: Macmillan.

Harper, S. R. (2009). Niggers no more: a critical race counternarrative on Black male student achievement at predominantly White colleges and universities. International Journal of Qualitative Studies in Education, 22(6), 697-712.

Harper, S. R., \& Harris, F. (2010). College men and masculinities : theory, research, and implications for practice (1st ed. ed.): Jossey-Bass.

Harper, S. R., \& Hurtado, S. (2007). Nine Themes in Campus Racial Climates and Implications for Institutional Transformation. New Directions for Student Services(120), 7-24.

Harper, S. R., \& Quaye, S. J. (2007). Student Organizations as Venues for Black Identity Expression and Development among African American Male Student Leaders. Journal of College Student Development, 48(2), 127-144.

Harper, S. R., Smith, E. J., \& Davis, C. H. F. (2016). A Critical Race Case Analysis of Black Undergraduate Student Success at an Urban University. Urban Education, 53(1), 3-25. 
Harris, C. (1993). Whiteness as Property. Harvard Law Review, 106(8), 1707-1791.

Harris, F., Palmer, R. T., \& Struve, L. E. (2011). "Cool Posing" on Campus: A Qualitative Study of Masculinities and Gender Expression among Black Men at a Private Research Institution. The Journal of Negro Education, 80(1), 47-62.

Harris, W. G. (2003). African American Homosexual Males on Predominantly White College and University Campuses. Journal of African American Studies, 7(1), 47-56.

Hattery, A., \& Smith, E. (2017). Policing black bodies: How black lives are surveilled and how to work for change.: Rowman \& Littlefield.

Henry, W. J., Fowler, S. R., \& West, N. M. (2011). Campus Climate: An Assessment of Students' Perceptions in a College of Education. Urban Education, 46(4), 689-718.

hooks, b. (2003). We Real Cool: Black Men and Masculinity. New York: Routledge.

Hurtado, S. (2015). Thinking About Race: The Salience of Racial Identity at Two- and FourYear Colleges and the Climate for Diversity. The Journal of Higher Education(1), 127.

Jackson, B. A., \& Wingfield, A. H. (2013). Getting Angry to Get Ahead: Black College Men, Emotional Performance, and Encouraging Respectable Masculinity. Symbolic Interaction, 36(3), 275-292.

Johnson, D. R. (2012). Campus Racial Climate Perceptions and Overall Sense of Belonging among Racially Diverse Women in STEM Majors. Journal of College Student Development, 53(2), 336-346.

Kim, Y. K. (2010). Racially Different Patterns of Student-Faculty Interaction in College: A Focus on Levels, Effects, and Causal Directions. Journal of the Professoriate, 3(2), 161189. 
Lacy, K. R. (2004). Black spaces, black places: Strategic assimilation and identity construction in middle-class suburbia. Ethnic \& Racial Studies, 27(6), 908-930.

Lamb, S., Kosterina, E. V., Roberts, T., Brodt, M., Maroney, M., \& Dangler, L. (2018). Voices of the Mind: Hegemonic Masculinity and Others in Mind during Young Men's Sexual Encounters. In (Vol. 21, pp. 254-275).

Lamont, M., \& Molnár, V. (2002). The Study of Boundaries in the Social Sciences. Annual Review of Sociology, 28, 167-195.

Lewis, A. E., Chesler, M., \& Forman, T. A. (2000). The Impact of "Colorblind" Ideologies on Students of Color: Intergroup Relations at a Predominantly White University. The Journal of Negro Education, 69(1/2), 74-91.

Lincoln, Y. S., \& Guba, E. G. (1985). Naturalistic Inquiry. Beverly Hills, CA: Sage Publications. Magubane, Z. (2002). Black Skins, Black Masks or 'The Return of the White Negro': Race, Masculinity, and the Public Personas of Dennis Rodman and RuPaul(3), 233.

Margolis, E. (2001). The Hidden Curriculum in Higher Education.

McClure, S. M. (2006). Improvising Masculinity: African American Fraternity Membership in the Construction of a Black Masculinity. Journal of African American Studies, 10(1), 5773.

McGee, E. O., \& Martin, D. B. (2011). "You would not believe what I have to go through to prove my intellectual value!": Stereotype management among academically successful Black mathematics and engineering students. American Educational Research Journal, $48(6), 1347-1389$. 
McGuire, K. M., Berhanu, J., Davis, C. H. F., \& Harper, S. R. (2014). In Search of Progressive Black Masculinities: Critical Self-Reflections on Gender Identity Development among Black Undergraduate Men. Men and Masculinities, 17(3), 253-277.

Nadal, K. L., Issa, M.-A., Leon, J., Meterko, V., Wideman, M., \& Wong, Y. (2011). Sexual Orientation Microaggressions: "Death by a Thousand Cuts" for Lesbian, Gay, and Bisexual Youth. Journal of LGBT Youth, 8(3), 234-259.

Pachucki, M. A., Pendergrass, S., \& Lamont, M. (2007). Boundary processes: Recent theoretical developments and new contributions. Poetics, 35(6), 331-351.

Park, J. J. (2014). Clubs and the Campus Racial Climate: Student Organizations and Interracial Friendship in College. Journal of College Student Development, 55(7), 641-660.

Park, J. J., Denson, N., \& Bowman, N. A. (2013). Does Socioeconomic Diversity Make a Difference? Examining the Effects of Racial and Socioeconomic Diversity on the Campus Climate for Diversity. American Educational Research Journal, 50(3), 466-496.

Ray, R., \& Rosow, J. A. (2010). Getting Off and Getting Intimate How Normative Institutional Arrangements Structure Black and White Fraternity Men's Approaches Toward Women. Men and Masculinities, 12(5), 523-546.

Ray, R., \& Rosow, J. A. (2012). The two different worlds of black and white fraternity men: visibility and accountability as mechanisms of privilege. Journal of Contemporary Ethnography(1), 66.

Saint-Aubin, A. F. (2002). A Grammar of Black Masculinity: A body of science. The Journal of Men's Studies, 10(3), 247 - 270.

Saldana, J. (2009). The coding manual for qualitative researchers. Thousand Oaks, CA: Sage. 
Seidman, I. E. (1991). Interviewing as Qualitative Research: A guide for researchers in education and social sciences. New York: Teachers College Press.

Smith, W. A., Allen, W. R., \& Danley, L. L. (2007). “Assume the Position . . You Fit the Description”. American Behavioral Scientist, 51(4), 551-578.

Smith, W. A., Hung, M., \& Franklin, J. D. (2011). Racial Battle Fatigue and the MisEducation of Black Men: Racial Microaggressions, Societal Problems, and Environmental Stress. The Journal of Negro Education, 80(1), 63-82.

Solorzano, D., Ceja, M., \& Yosso, T. (2000). Critical Race Theory, Racial Microaggressions, and Campus Racial Climate: The Experiences of African American College Students. The Journal of Negro Education, 69(1/2), 60-73.

Solórzano, D. G., \& Yosso, T. J. (2002). Critical Race Methodology: Counter-Storytelling as an Analytical Framework for Education Research. Qualitative Inquiry, 8(1), 23-44.

Steele, C. M. (1997). A Threat in the Air: How stereotypes shape intellectual identity and performance. American Psychologist, 52(6), 613 - 629.

Stewart, D.-L. (2017). Black Collegians' Experiences in US Northern Private Colleges: A Narrative History, 1945-1965: Springer.

Strayhorn, T. L., \& Tillman-Kelly, D. L. (2013). Queering Masculinity: Manhood and Black Gay Men in College. Spectrum: A Journal on Black Men, 1(2), 83-110.

Summers, M. (2004). Manliness and its Discontents: The Black Middle Class and the Transformation of Masculinity, 1900 - 1930. Chapel Hill and London: The University of North Carolina Press.

Turner, C. S. V. (1994). Guests in Someone Else's House: Students of Color. Review of Higher Education, 17(4), 355-370. 
Tynes, B. M., Rose, C. A., \& Markoe, S. L. (2013). Extending Campus Life to the Internet: Social Media, Discrimination, and Perceptions of Racial Climate. Journal of Diversity in Higher Education, 6(2), 102-114.

Weitzer, R. (2000). Racialized policing: Residents' perceptions in three neighborhoods. Law \& Society Review, 34(1), 129-155.

White, M. (2011). From Jim Crow to Jay-Z : Race, Rap, and the Performance of Masculinity. Urbana: University of Illinois Press.

Whitehead, S. M., \& Barrett, F. (2001). The Sociology of Masculinity. In S. M. Whitehead \& F. Barrett (Eds.), The Masculinities Reader (pp. 1 - 26). Cambridge, England: Polity Press.

Wilkins, A. C. (2012a). "Not Out to Start a Revolution": Race, Gender, and Emotional Restraint among Black University Men. Journal of Contemporary Ethnography, 41(1), 34-65.

Wilkins, A. C. (2012b). Stigma and status: Interracial intimacy and intersectional identities among Black college men. Gender \& Society, 26(2), 165-189.

Woodford, M. R., Howell, M. L., Kulick, A., \& Silverschanz, P. (2013). "That's so Gay": Heterosexual Male Undergraduates and the Perpetuation of Sexual Orientation Microagressions on Campus. Journal of Interpersonal Violence, 28(2), 416-435.

Young, A. (2004). The minds of marginalized black men: Making sense of mobility, opportunity, and future life chances. Princeton, NJ Princeton Univ. Press. 